Izabella GRABOWSKA-LEPCZAK

The Main School of Fire Service ${ }^{1}$

Faculty of Safety Engineering and Civil Protection

Department of Social Sciences

igrabowska@sgsp.edu.pl

ORCID 0000-0003-4695-3993

https://doi.org/10.34739/dsd.2021.01.09

\title{
THE ROLE OF EDUCATION IN SHAPING SAFE BEHAVIOURS AND ATTITUDES IN THE ASPECT OF SUSTAINABLE DEVELOPMENT
}

\author{
"IMAGINATION IS MORE IMPORTANT THAN KNOWLEDGE. \\ KNOWLEDGE IS LIMITED. IMAGINATION ENCIRCLES THE WORLD.” \\ ALBERT EINSTEIN
}

\begin{abstract}
Education for safety is an exceptionally relevant issue in the modern world. It is an indispensable tool for achieving the goals of sustainable development. Who, when and where to educate; what tools to use; and according to what idea - these are essential questions related to raising human awareness. The aim of the article is to analyze and assess the awareness of society in terms of knowledge and skills in the field of safe behavior and attitude, the perception of safety in the context of sustainable development. The results of the research presented in the article clearly indicate a high level of public involvement in acquiring knowledge and skills on safe behaviours and attitudes. The conclusions obtained allow to develop a strategy that will permit to develop an education system for safety (that will consider formal and informal education) as well as selfeducation. These conclusions constitute the basis for building cooperation between central government and local government units, educational units, and non-governmental organisations.
\end{abstract}

KEYWORDS: education, safety, education for safety, society, sustainable development

\section{ROLA EDUKACJI W KSZTALTOWANIU BEZPIECZNYCH ZACHOWAŃ I POSTAW W ASPEKCIE ZRÓWNOWAŻONEGO ROZWOJU}

\begin{abstract}
ABSTRAKT: Edukacja dla bezpieczeństwa jest zagadnieniem niezwykle istotnym we współczesnym świecie. Stanowi również niezbędne narzędzie do osiągania celów zrównoważonego rozwoju. Celem artykułu jest ocena wiedzy i umiejętności społeczeństwa w zakresie bezpiecznych zachowań i postaw, postrzegania bezpieczeństwa w kontekście zrównoważonego rozwoju. Przedstawione w artykule wyniki badań wskazują na wysoki poziom zaangażowania społecznego w zdobywanie wiedzy i umiejętności dotyczących bezpieczeństwa. Uzyskane wyniki badań pozwola na wypracowanie strategii, która może mieć realny wpływ na rozwój systemu edukacji dla bezpieczeństwa (uwzględniającego edukację formalną i nieformalną) oraz samokształcenie. Edukacja społeczeństwa powinna być działaniem kompleksowym, właściwie zaprogramowanym, polegającym na współdziałaniu wielu instytucji rządowych, samorządowych, organizacji pozarządowych, służb oraz instytucji i placówek oświatowych.
\end{abstract}

SŁOWA KLUCzowE: edukacja, bezpieczeństwo, edukacja dla bezpieczeńśtwa, społeczeństwo, zrównoważony rozwój

${ }^{1}$ Szkoła Główna Służby Pożarniczej; Polska. 


\section{INTRODUCTION}

The new 2030 Agenda for Sustainable Development, adopted in 2015 by world leaders at the UN Summit, points to the need to introduce education principles for sustainable development at all levels. By pursuing the 17 sustainable development goals and targets, education contributes to creating more socially sustainable and fair societies. It is worth noting that most of them refer to categories and indicators related to education ${ }^{2}$.

Educating contemporary society (especially children and youth) for sustainable development plays a substantial role in shaping appropriate behaviour patterns and attitudes. The main purpose of this type of education is to raise the level of awareness in relation to harmonious and safe coexistence with nature, and to shape responsibility towards the natural environment. It is important to be prepared to take appropriate measures and actions that protect nature and improve the state of the natural environment as well as ensure rational and safe use of natural resources. For this education to be effective, it should be flexible and serve fundamental social changes ${ }^{3}$.

Education is an indispensable tool for achieving sustainable development. Awareness, education and training are crucial to sustainable development. Education ensures constant improvement of the ways in which we explore our world. It makes it possible for us to understand the mechanisms that control the world of nature, culture, and society. Education is not only about the process, but also about self-education. All forms of education serve these purposes - otherwise society will not invest in $\mathrm{it}^{4}$.

In accordance with the fourth objective of the Sustainable Development Goals (Ensure inclusive and equitable quality education and promote lifelong learning opportunities for all), the quality of education as well as the ability to be able to learn throughout one's life are the most important aspects of an effective life for all involved and for achieving sustainable development ${ }^{5}$.

\footnotetext{
${ }^{2}$ Cf V. Kioupi, N. Voulvoulis, Education for Sustainable Development: A Systemic Framework for Connecting the SDGs to Educational Outcomes, "Sustainability" 2019, 11 (21), p. 6104; M. Gruchelski, J. Niemczyk, The 2030 Agenda for sustainable development goals and sustainable, development goals - chances of implementation in: Postępy techniki przetwórstwa spożywczego 1/2016, pp. 22-125.

${ }^{3}$ E. Buchcic, Educating young people for sustainable development at different stages of teaching, p. 105; A. Stankiewicz, Implementation of sustainable development assumptions in the declaration of students of physics in: Education and sustainable development in a unifying Europe, ed. E. Rydz and A. Kowalik, Słupsk 2005, pp. 145; J. Sandner, Selected aspects of environmental processes of holistic nature education in the light of the idea of sustainable development, pp. 6980, in: Sustainable development problems, 2008 3(2); Shih-Yeh Chen, Shiang-Yao Liu, Developing Students' Action Competence for a Sustainable Future: A Review of Educational Research, “Sustainability” 2020, 12(4), p. 1374.

${ }^{4}$ K. Drabik, Personal and structural security, Warsaw 2013, pp. 321., M. Marciniuk, Education for security a condition for safeguarding national interests in: Education for security. National security strategy - social and economic executive support, ed. M. Ilnicki, J. Kufel, Poznań 2015, pp. 35., Education for Sustainable Development Toolkit, Version 2, R. McKeown, Center for Geography and Environmental Education University of Tennessee, July 2002, pp. 16-23; A. Leicht, B. Combes, W.J. Byun, A.V. Agbedahin, From Agenda 21 to Target 4.7. the development of Education for Sustainable Development; A. Leicht, J. Heiss, W.J. Byun, Issues and trends in Education for Susitainable Development, UNESCO Publishing 2018, A. Batorczak, Education for Sustainable Development in Poland and Great Britain - doctoral dissertation, Warsaw 2013, pp. 22-30.

${ }^{5}$ Special edition: progress towards the Sustainable Development Goals Report of the Secretary-General, Economic and Social Council, 8 May 2019, p. 10.
} 


\section{THEORETICAL BASICS}

The dictionary of foreign words and English language phrases compiled by Władysław Kopaliński indicates that education is primarily a question of one's upbringing and training (etymology: Latin educatio 'aa.' from educare "upbringing; education"; e- 'wy-'; -ducare from ducere $)^{6}$.

In the modern sense of education, substantial emphasis is placed on the possibility of developing personality, and not just on meeting the learning targets for a given subject.

Currently, the following four main trends of education can be clearly distinguished:

- the knowledge acquirement,

- the ability to learn,

- the ability to understand others,

- personal development.

In this article, education (as a term) will refer primarily to the question of upbringing and training of society in the area of safety. The main purpose of this education is to develop awareness of the whole society in the area of safety and to develop habits that strengthen safety. This requires the involvement of numerous institutions, starting with family, school, and including the media and public authorities ${ }^{7}$.

Education can be conducted both formally and informally. Formal education is understood as a system that is based on solid content and forms of designed learning from initial schooling to university. This system also includes all courses and programmes offered by educational institutions. Informal education is any activity having the characteristics of education and upbringing, but carried out outside the statutory formal schooling system ${ }^{8}$.

Education is crucial in promoting sustainable development and improving people's ability to cope with the environment in which they live. Both formal and informal education is necessary to change people's attitudes so that they have the ability to assess and solve problems related to sustainable development. Informal education includes all activities that are aimed at expanding knowledge and acquiring practical skills. This form is based mainly on practice and experience, it differs from formal education mainly in its methodology. It includes both expanding knowledge and skills as well as shaping attitudes and values ${ }^{9}$.

\footnotetext{
${ }^{6}$ W. Kopaliński, Dictionary of foreign words and phrases, Warsaw 1999, p. 140.

${ }^{7}$ M. Lorek, Education for Security as a Link in the Security System, "Edukacja - Technika - Informatyka" 2017 4(22), pp. 286-287.

${ }^{8}$ Cf G. Cebrian, M. Junyent, I. Mula, Competencies in Education for Sustainable Development: Emerging Teaching and Research Developments, "Sustainability" 2020, 12(2), p. 579; E. Kral, Environmental education of local communities and ecological awareness of urban housing residents, in: Environmental education of local communities, ed. L. Tuszyńska, Warsaw 2006, pp. 54-55; I. Żeber-Dzikowska, Ecological education in the 21 st century - education for all, in: Education and sustainable development in a unifying Europe, Shupsk 2005, p. 64.

${ }^{9}$ Cf J. Ropski, Detailed didactics of education for safety, Katowice 2013, pp. 185-192; E. Włodarczyk, Qualifications of education teachers for safety, Security of the modern state, National dimension, ed. J. Falecki, P. Łubiński, Kraków 2019, pp. 218-220; A. Kuzior, Dekada Edukacji dla Zrównoważonego Rozwoju, „Zeszyty Naukowe Politechniki Śląskiej” 2014, Series: Organizacja i zarządzanie, from 72 Coll. Issue 1918, pp. 92-93.
} 
Both formal and informal education fit the assumptions of sustainable development, especially in chapter 36 of Agenda 21, where we can find provisions that relate to the promotion of education and public awareness. These elements are practically related to all principles of sustainable development. Education, including formal education, as well as public awareness and training, should be considered a process in which society can reach its full potential ${ }^{10}$.

Reflections regarding education for safety were undertaken here due to the importance of the issues and the need to monitor and raise public awareness of safety. Not only awareness, the level of knowledge and skills of the society are important, but also the adaptation of forms of education and using the most modern educational tools.

\section{RESEARCH IN THE FIELD OF EDUCATION FOR SAFETY}

The humanistic and social approach to creating an education system for safety is associated with the need to conduct research in the field of analysing knowledge, beliefs, and public awareness in the aspect of safety. The background, as well as the starting point for the research designed here were previous analyses of literature in the area of public education in the area of safety, as well as the research conducted by the author of the article between the years of 2008-2019. The analyses included, amongst others, the education for the safety system, the assessment of the implementation of tasks in the field of education for safety by local authorities, and research on the impact of media on the culture of safety. In this area, it was important to examine which media (and to what extent) have an impact on shaping public awareness concerning safety. These studies allowed the submission of conclusions that would prove, above all, the important role of educational organisations in raising public awareness of safety, the great need to implement such ventures, and the need to use modern tools in this field of education. The need to adapt the subject to contemporary natural and civilisation threats is also becoming essential ${ }^{11}$.

The results (preliminary) of the research presented in the articleclearly relate safety and education for safety. The originality of the proposed research is due to the adoption of the concept of social needs as superior to the organisational state system.

The aim of the research was to check the level of society's awareness of safety. The research problem was formulated as follows: What level of knowledge about security does Polish society have? The basic hypothesis of the research was that the state of society's knowledge of safety is at a high level. The second hypothesis was that school-age children and adolescents are better equipped with knowledge and skills to cope with crisis situations than adults, it should be pointed out that the age of about $30 \%$ of respondents was under 25 years old.

\footnotetext{
${ }^{10}$ Cf United Nations Conference on Environment \& Development, Rio de Janerio, Brazil, 3 to 14 June 1992 , AGENDA 21, Chapter 36., Education for Sustainable Development Toolkit, R. McKeown, Version 2, July 2002, Center for Geography and Environmental Education, University of Tennessee, pp. 13-15.

${ }^{11}$ I. Grabowska-Lepczak, Edukacja dla bezpieczeństwa. Aspekty praktyczne i teoretyczne, Warsaw 2017, pp. 77-173.
} 
It is worth understanding that education in the area of safety is a great opportunity to develop prevention in terms of shaping proper behaviours and attitudes, and creating appropriate values for the protection of health, human life, and the environment ${ }^{12}$.

Consistent and systematic implementation of tasks in this area will allow to achieve the proper level of human awareness. At this point, it should be noted that educational institutions should fulfil their role with seriousness and dedication. The small number of scientific publications and research proves the necessity to fill the gap in this area. The aim of the presented research was to check the level of public knowledge about safety. Important element was to determine whether people who are not professionally involved in safety are willing to acquire knowledge about safe behaviours and attitudes on their own and to identify sources of information. An important aspect was also to determine the interest of the respondents in their own safety.

The scenario of the projected research was based on the assumptions of modern civil protection systems, of which security education is an integral part. The research included an analysis of the literature on education, education for safety and social security. In the second part, a research tool was designed - it was a questionnaire prepared for the specific needs of the discussed topic. The selection of the literature and the questionnaire allowed for analytical conclusions and appropriate unification and interpretation of the results.

The survey research was conducted using a questionnaire. The results of the verification test may be the basis for confirming or rejecting the hypothesis, i.e., the presumed, anticipated answer to the question contained in the research problem. The questionnaire was made available electronically without the participation of the interviewer. The selected sample was selected randomly. The applied quantitative and qualitative research allowed for deepening the knowledge about safety. After the analysis, the collected information was presented in a descriptive manner and in charts. An important part of the questionnaire was also the record, which was used to obtain the necessary information about the individual characteristics of the respondent, such as: age, gender, place of residence. This enables the analysis of the collected data in terms of selected characteristics of the respondents.

The research was carried out in Poland. The questionnaire contained mostly categorised questions and some open-ended questions. The expected duration of the survey was 35 minutes. The sample was random and purposeful - it included 144 respondents. These are its characteristics:

\begin{tabular}{|l|c|c|}
\hline \multicolumn{1}{|c|}{ Gender } & Occurrence & \% \\
\hline 1. Female & 70 & 49 \\
\hline 2. Male & 74 & 51 \\
\hline
\end{tabular}

Table 1. Respondents' gender

$(\mathrm{N}=144)$

\footnotetext{
${ }^{12} \mathrm{Cf}$ A. Skrabacz, The national character of Poles and its impact on the education process for the safety of Poles, in: Security as an educational process, ed. A. Pieczywok, K. Loranty, Warsaw 2015, pp. 77-83; D. Riegert, M. Wachnik, Importance of education for safety, "Journal of Modern Science” 2016 3(30), pp. 317-333.
} 


\begin{tabular}{|c|c|c|}
\hline Age & Occurrence & \% \\
\hline $9-15$ & 5 & 3 \\
\hline $16-25$ & 50 & 35 \\
\hline $26-40$ & 45 & 31 \\
\hline $41-50$ & 40 & 28 \\
\hline Over 50 & 4 & 3 \\
\hline
\end{tabular}

Table 2. Respondents' age

$(\mathrm{N}=144)$

When analysing the presented lists, it should be noted that the gender and age indicators are evenly distributed - especially in the 16-50 age group. Conducting the study in different regions of Poland should be treated as a spatial dispersion of the sample, and thus its greater representativeness. It should be pointed out that the quantitative predominance occurs in the Mazowsze Voivodeship.

\section{Presentation OF Results}

The data source was a research questionnaire prepared on the basis of literature analysis and on the work carried out in the field of education for safety within the framework of statutory research carried out in the years 2008-2019 at the Main School of Fire Service. The sample consisted of 144 respondents. The result of the research is an analysis of the public awareness of safety. The final results of the research will be important for developing a way to educate society in the field of civil security by developing awareness among society in this area and familiarising it with the problems of dealing with selected threats.

\section{ARE YOU EMPLOYED IN THE SAFETY PROFESSION?}

Are you employed in the safety profession?

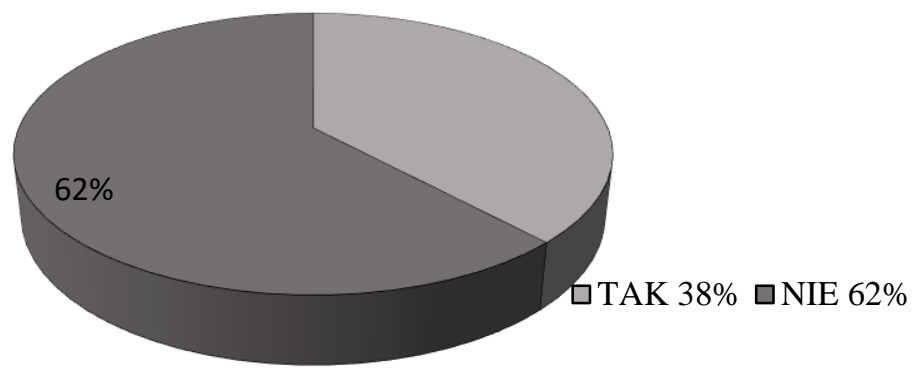

Diagram 1. Are you employed in the safety profession?

Source: Own research, Warsaw 2021, N= 144

This question was answered affirmatively by almost $38 \%$ of respondents. Therefore, it can be assumed that this group of respondents' levels of knowledge is above average. This was reflected mainly in the formulation of safety thoughts and definitions. The method of 
response is evident in the case of professionals versus people who do not deal with safety on a daily basis. This can be clearly seen in the next question.

\section{WHAT DOES SAFETY MEAN TO YOU?}

This question is essential to identify the basic areas that are mentioned by the respondents and to indicate first of all those elements that determine their sense of security as well as the way they perceive them.

The answers are grouped as follows. The largest number of respondents (about 50\%) replied that for them the safety is, first and foremost, about the absence of threats or danger. The remaining answers were:

- A field of science dealing with probable risks and ways to counteract them.

- A state in which a person feels safe, but that does not necessarily mean that there is no danger.

- To ensure an adequate level of protection of both human life and material goods.

- A condition where all risks/hazards are at a level acceptable to me.

- The level of risk which is a product of the probability of an event and its consequences.

- A wide range of topics from road safety through construction disasters to terrorist attacks.

- A process in which all sectors and citizens take part to maintain the prevailing peace, to shape conscious attitudes and assist in the development of the state, its culture, and similar units.

- Ensuring that all risks are minimised.

- Comprehensive measures to ensure the protection of people's health and lives.

- It is a condition and process of experiencing the least amount of possible danger.

- A set of actions ensuring peaceful, sustainable well-being.

- Safety: public, social, family, individual, economic, ecological.

- It is a state in which entities operating within its scope try to improve the mechanisms ensuring a sense of security.

- Protection of society provided by relevant forces.

- Systemic solutions against potential threats.

- Lack of fear for life, health, or freedom.

- The ability to deal with threats, comprising of unusual, extraordinary situations.

- Being part of a group and depending on it for support.

- Ensuring respect for human dignity.

- Satisfying basic human needs.

- Chance for development. The possibility of implementing one's own plans.

The range of answers was very wide. There are definitions referring to central and local governmental structures whose task is to protect the population and human life, as well as references 
to a sense of safety, the level of which determines the satisfaction of needs and the pursuit of selfdevelopment. In general, safety is positively described as one of the most important values ${ }^{13}$.

An interesting element is the indication of belonging to a group that provides support through a sense of security and peace. The analysis of answers shows that people dealing with safety often define the concept in a systemic and institutional way, while other people referred mainly to the subjective perception of safety, to the sense of security.

\section{IS YOUR PERSONAL SAFETY IMPORTANT TO YOU?}

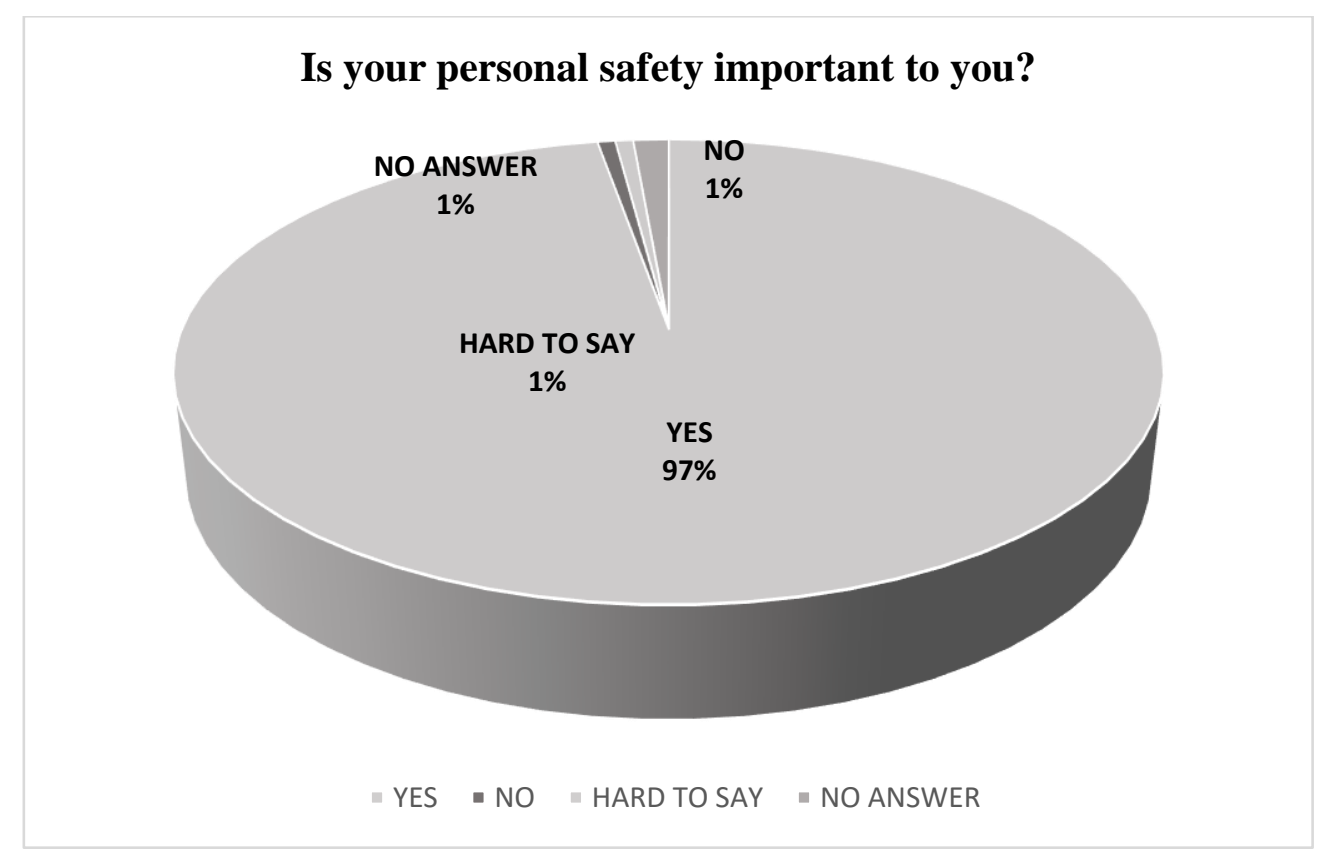

Diagram 2. Is your personal safety important to you?

Source: Own research, Warsaw 2021, N=144

This question was important because of the assumption that for young people safety is not as important as it is for middle-aged and older people. However, as the answers indicate, as many as $97 \%$ of the respondents indicated that it is important for them.

\footnotetext{
${ }^{13}$ Cf K. Olak, A. Olak, Modern understanding of national security, "Acta Scientifica Academiae Ostroviensis" 2016 7(1), pp. 468-471., A. Czupryński, Theoretical security, Safety: Theory - Research - Practice, ed. A. Czupryński, B. Wiśniewski, J. Zboina, Józefów 2015, pp. 10-12.
} 


\section{WHAT, IN YOUR OPINION, ARE THE GREATEST THREATS IN YOUR REGION?}

\section{THE GREATEST THREATS IN YOUR REGION}

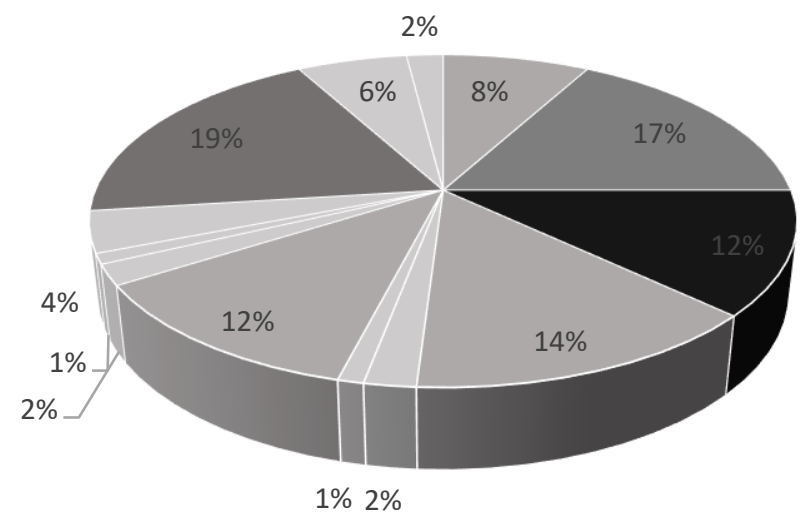

- sanitary and epidemiological hazards $8 \%$. - fires $17 \%$

- floods $12 \%$

- storms and hurricanes $14 \%$

- snowstorms, snowbank and icing $2 \%$

- avalanches $1 \%$

- droughts, heat $12 \%$

- earthquakes $2 \%$

- radioactive contamination $1 \%$

- rail crashes $4 \%$

- road crashes $19 \%$

- construction disasters $6 \%$

air disasters $2 \%$

Diagram 3. The greatest threats in your region Source: Own research, Warsaw 2021, N=144.

Modern times are characterised by the occurrence of natural disasters, industrial and communication failures. It is predicted that these phenomena will continue to grow despite the creation of increasingly sophisticated security systems. In spite of continuous scientific and technical progress, people are not able to control the force majeure, which brings about considerable losses among people and their property. The threats presented in this question concern precisely natural, anthropogenic and social aspects. The task of the respondents was to indicate those threats whose occurrence is greatest in their area of residence. The majority of responses mentioned road crashes (20\%), fires (17\%), storms and hurricanes (14\%), droughts and heat $(12 \%)$, and sanitary and epidemiological hazards (8\%). Other responses to the remaining threats were between $1 \%$ and $4 \%$. 


\section{HOW DO YOU ASSESS YOUR KNOWLEDGE AND SKILLS IN DEALING WITH THESE THREATS?}

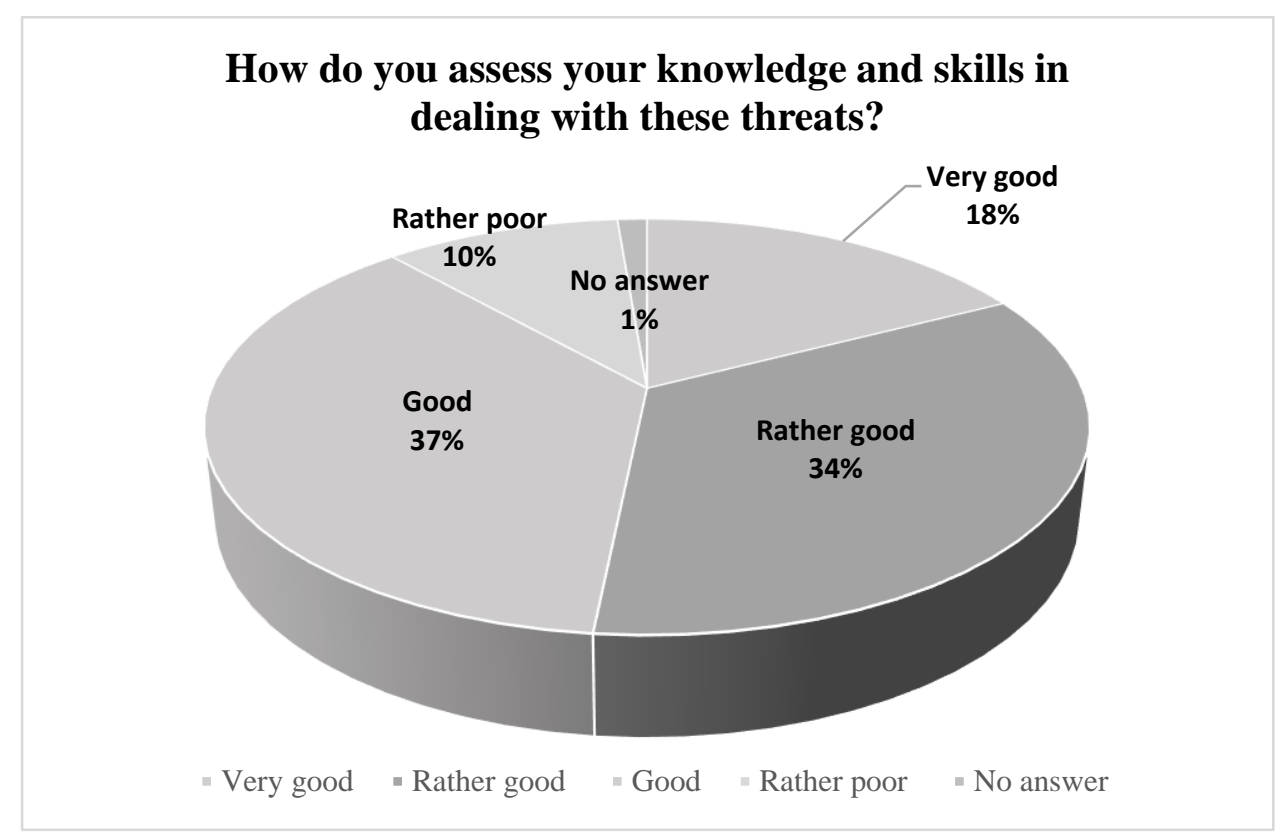

Diagram 4. Knowledge and skills in dealing with these threats. Sourc: Own research, Warsaw 2021, $\mathrm{N}=144$.

This question concerned the assessment of their skills and knowledge of how to deal with the risks identified in the previous questions. The respondents assessed themselves rather positively. In the categories good and rather good, $73 \%$ of respondents assessed their skills as very good. As many as $18 \%$ assessed their skills as very good, and $8 \%$ believed that they would not be able to behave properly in the case of one of the threats popped up.

\section{HAVE YOU EVER TAKEN A CLASS THAT WOULD TEACH YOU HOW TO DEAL} WITH SUCH THREATS?

\section{Have you ever taken a class that would teach you how to deal with such threats?}

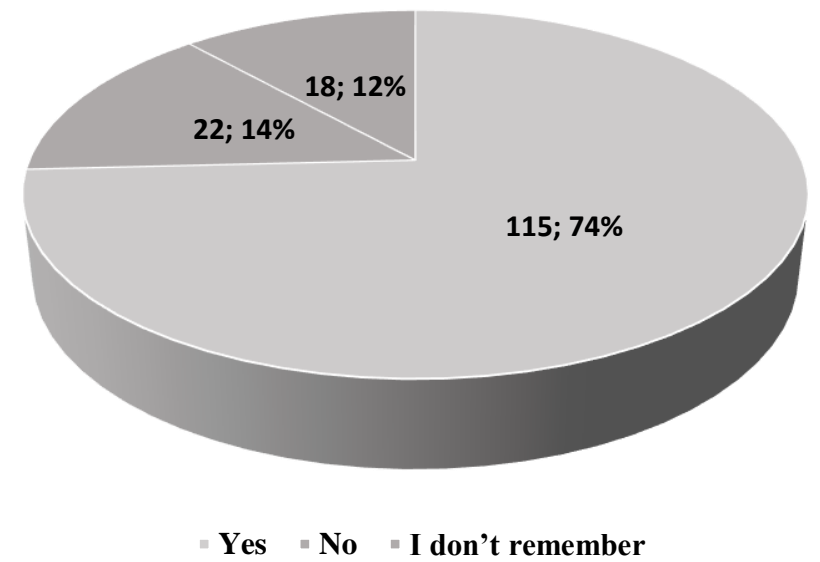

Diagram 5. Participation in educational events that would teach how to deal with such threats Source: Own research, Warsaw 2021, N=144. 
In this respect, a high percentage of affirmative answers (78\% of respondents) show that safety education is provided at a high level in schools, and given the respondents who are outside the compulsory schooling system, this result is also very good. Only $12 \%$ of people indicated that they did not participate in any safety education.

\section{WHERE DO YOU GET YOUR SAFETY INFORMATION FROM?}

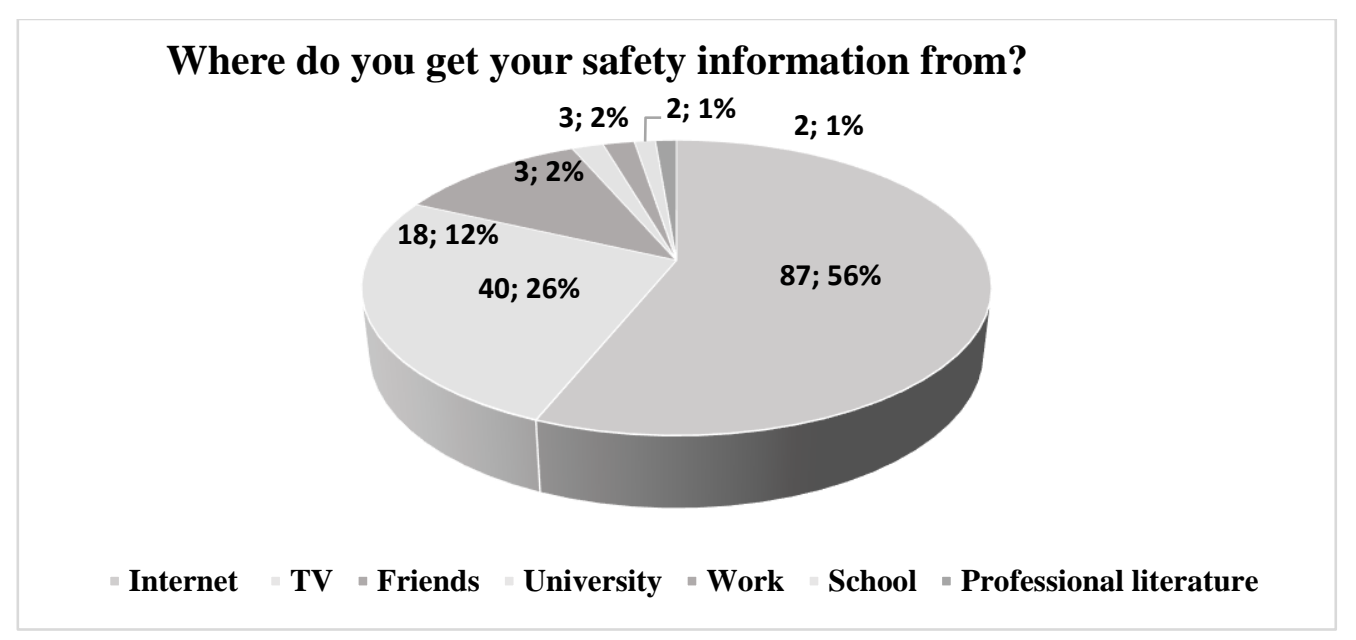

Diagram 6. Information concerning safety

Source: Own research, Warsaw 2021, N=144.

The answers given by the respondents indicate that the basic source of knowledge concerning safety is the Internet, closely followed by television, friends, universities, primary schools, and professional literature. At this point it is worth mentioning that in the case of knowledge drawn from mass media, it becomes important to choose reliable sources. For those who are involved in educating the public about safety, this is the starting point for designing campaigns and programmes in this area. Furthermore, the survey shows that the majority of respondents (75\%) attending school had a school subject related to safety (depending on the age of the respondents, it was, e.g., safety education, defence training).

\section{FROM WHOM WOULD YOU EXPECT THE MOST HELP IN AN EMERGENCY?}

The next question (Who will help you in an emergency) was an open-ended question. Here, most of the respondents indicated rescue services - mostly the fire brigade, then the police, ambulance service, local crisis management team, local authorities, friends, and family. The majority of respondents answered in a similar way regardless of their nationality, address of residence, or age.

\section{WHO DO YOU THINK IS RESPONSIBLE FOR SAFETY IN YOUR TOWN?}

The answers in this case were also very consistent. The respondents selected mainly rescue services, local governments, local authorities, the Minister of Interior and Administration, as well as themselves as responsible for security in their place of residence. 


\section{ARE YOU FAMILIAR WITH ANY SAFETY PROGRAMMES OR CAMPAIGNS?}

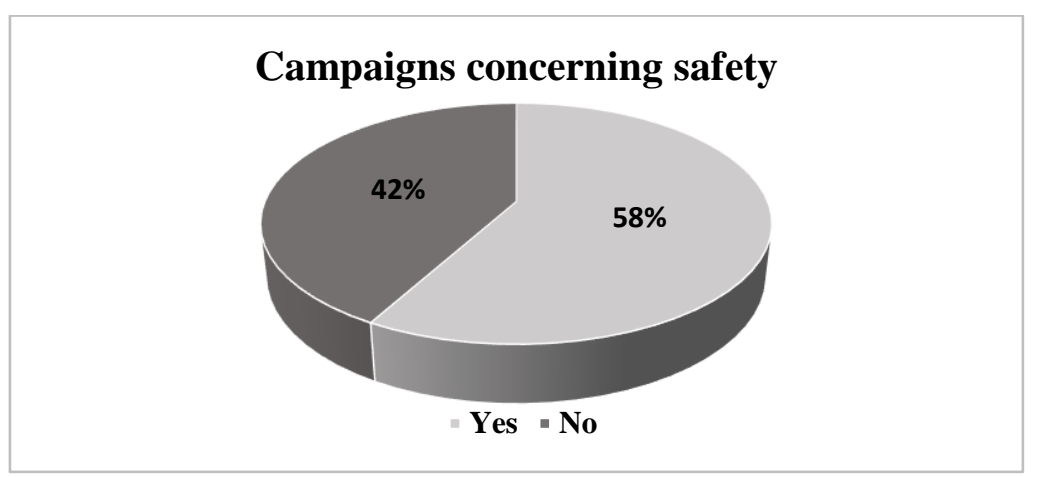

Chart 7. Campaigns concerning safety

Source: Own research, Warsaw 2021, N=144.

As many as $58 \%$ of respondents answered affirmatively to the question concerning their knowledge of security programmes or campaigns. The main topics that were mentioned were as follows: online safety, road safety, safe school, "stop burning grass" activities, waterside safety, evacuation, burglar alarm detectors to protect your safety, "Safety Excites Me" programme, safe holidays, air quality, and flood and fire prevention.

\section{WHAT DO YOU THINK IS THE BEST WAY TO LEARN ABOUT SAFETY?}

Most respondents stated that the best was would be at educational meetings with a fireman or a policeman $(55 \%)$. Secondly, it was indicated that directly during classes with a teacher $(25 \%)$, then through the mass media (20\%), and finally - reading brochures and leaflets $(5 \%)$.

\section{WHICH TOOLS DO YOU THINK ARE MOST EFFECTIVE IN PROMOTING SAFETY?}

In the first place, the respondents pointed out that the most effective way of communicating information was through social campaigns and demonstrations (80\%), followed by brochure leaflets $(10 \%)$ and, subsequently, by taking part in safety-themed competitions (9\%).

\section{DO YOU TRY TO ACQUIRE SKILLS AND KNOWLEDGE CONCERNING SAFETY ON YOUR OWN?}

\section{Do you try to acquire skills and knowledge concerning safety on your own?}

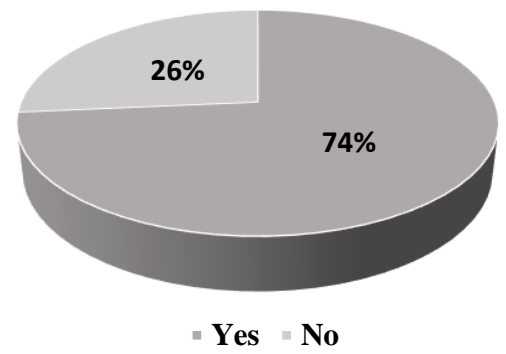

Diagram 8. Acquiring knowledge concerning safety Source: Own research, Warsaw 2021, N= 144. 
The majority of the respondents replied that they were interested in the subject of safety and tried to obtain information on their own. This is a very good result, consistent with the previous answers and the attitude of the respondents.

\section{WHICH TOPICS ON SAFETY ARE YOU MOST INTERESTED IN?}

The topics that were most frequently mentioned were as follows: public safety (as many as 25 individuals), fire, traffic, civil protection, cyber-protection, first aid, evacuation, children's safety, NGO tasks, anti-terrorism education, natural disasters, water and mountain safety, safety in public transport, contemporary security risks, safety of the elderly, epidemiological risks, environmental safety.

As presented above, the spectrum of interest in the area of respondents' safety is very wide. It is connected both with professional interests and with situations which are close to the respondents' everyday life.

The next set of questions concerns issues related to the practical skills of the respondents.

\section{HAVE YOU EVER PARTICIPATED IN AN EVACUATION DRILL?}

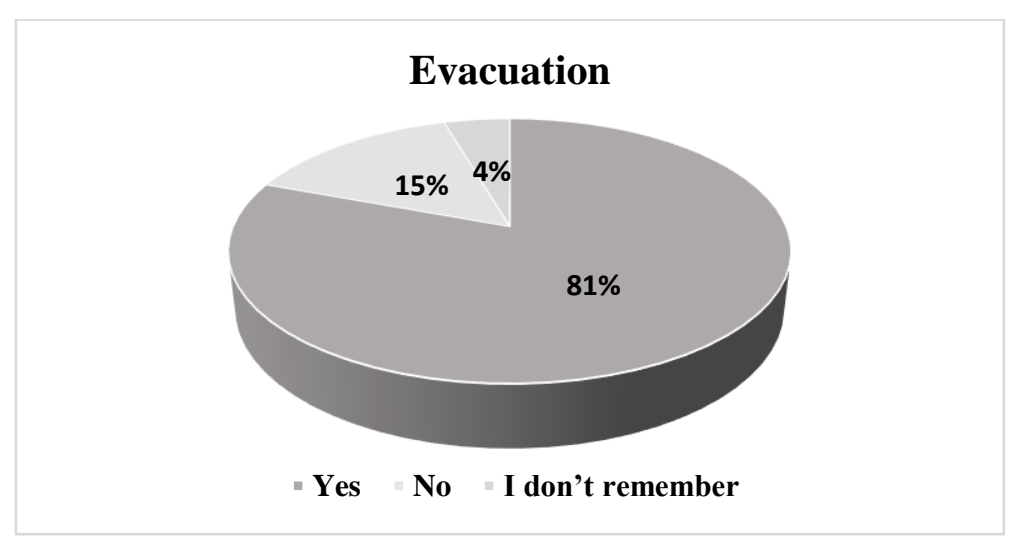

Diagram 9. Evacuation

Source: Own research, Warsaw 2021, N=144.

Conducting an evacuation drill is a statutory obligation - not only in Poland. In the order of the Minister of Interior Affairs and Administration of 07 June 2010 concerning the fire protection of buildings, other buildings and areas in $\S 17$ of the Fire Protection Act, the practical verification of the organisation and conditions of evacuation are stated in point 1 , "The owner or manager of a facility intended for more than 50 persons, who are its permanent users, not classified as ZL IV persons, should at least once every two years carry out a practical check of the organisation and conditions of evacuation from the entire facility"; and further on, in point 2, "In relation to facilities such as: schools, nurseries, student houses, it is necessary to check the evacuation conditions once a year". ${ }^{14}$

\footnotetext{
${ }^{14}$ Ordinance of the Minister of the Interior and Administration on the fire protection of buildings, other building structures and areas, Journal of Laws 2010 no. 109 item 719.
} 
In this case, as many as $85 \%$ of the respondents replied that they had taken part in an evacuation drill (mainly as a primary or secondary school student). However, $14 \%$ respondents have never participated in such activities.

\section{HAVE YOU EVER TAKEN PART IN AN ANTI-TERRORIST TRAINING COURSE?}

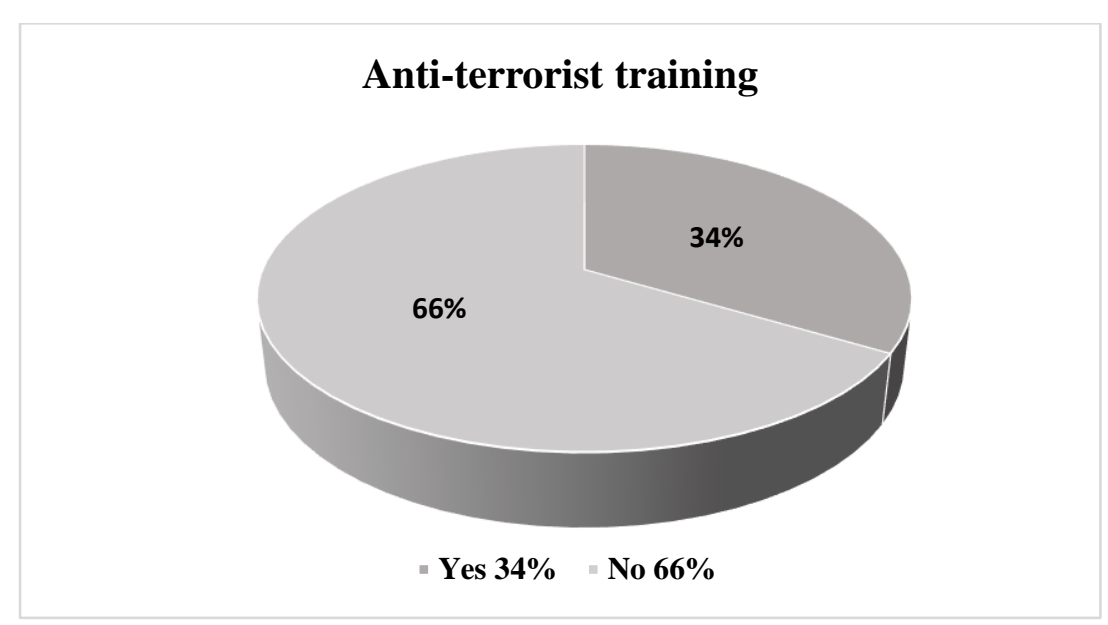

Diagram 10. Anti-terrorist training

Source: Own research, Warsaw 2021, N=144.

Anti-terrorism education is still a relatively new topic, certainly less common than road safety education or fire-fighting. This is confirmed by the answers of the respondents, as only one in three of them stated that they had taken part in such training courses.

\section{ARE YOU FAMILIAR WITH ANY APPLICATIONS PROMOTING SAFETY?}

The next question pertained to acquired knowledge of safety applications. Respondents showed a very good level of their familiarity with most of the available safety applications (e.g., Akut, Kızllay, Mass Event Security, RCB, RSO, For help). Specialist websites were provided by professional security professionals, while other respondents mentioned apps for all users. It is worth noting, however, that the knowledge concerning the current available materials is satisfactory.

\section{DO YOU KNOW ANY WEBSITES PROMOTING AND TEACHING SAFETY? IF SO, PLEASE PROVIDE AN ADDRESS OR TOPIC.}

The respondents answered the question whether they were familiar with websites promoting safety in a similar fashion. The specified web addresses included bezpiecznewakacje.pl, straz.gov.pl, niebezpiecznik.pl, Safety and Work Hygiene; KGPSP (National Headquarters of the Polish Fire Brigade) https://www.straz.gov.pl/ (training materials), Internet danger map, naszebezpieczenstwo.strefa.pl.

Specialist websites were provided by persons dealing with professional safety, whereas other respondents indicated applications intended for all users. However, it is worth noting that the amount and value of knowledge on available applications is satisfactory. 


\section{HAVE YOU EVER TAKEN A FIRST AID COURSE?}

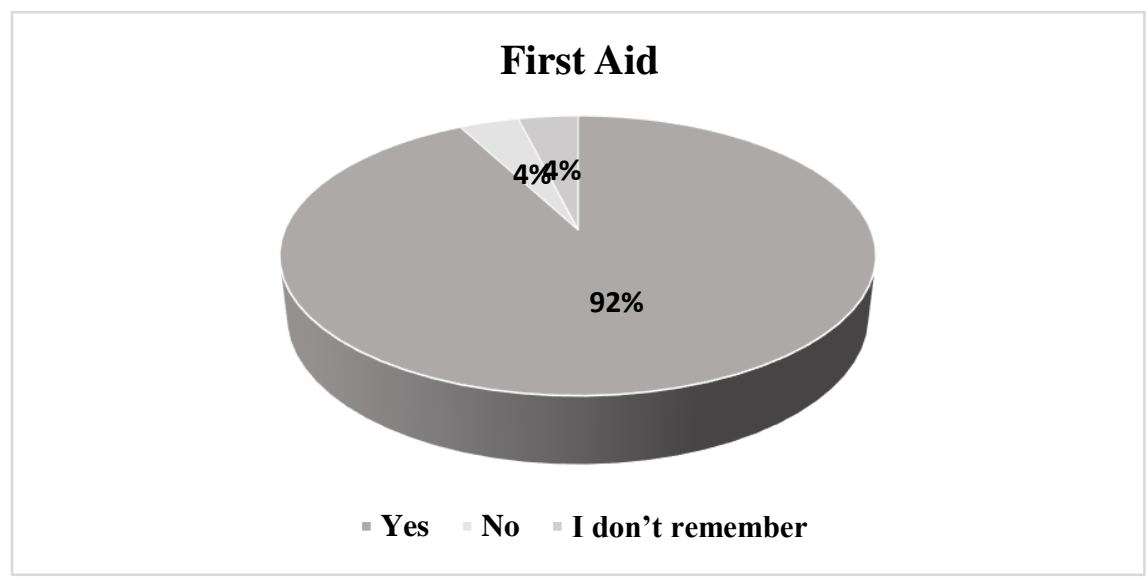

Diagram 11. First aid

Source: Own research, Warsaw 2021, N= 144

As many as $97 \%$ of the respondents stated that they had taken a first aid course. This is a very good result.

\section{DO YOU THINK FIRST AID TRAINING SHOULD BE COMPULSORY?}

Do you think first aid training should be compulsory?

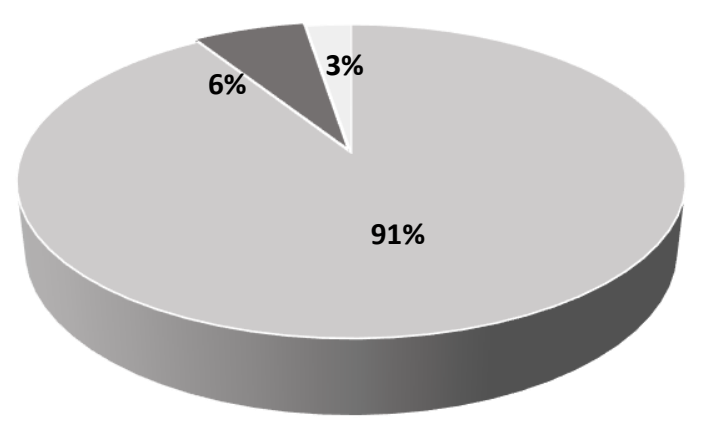

Yes 91\% - No 6\% Hard to say 3\%

Diagram 12. First aid education

Source: Own research, Warsaw 2021, N=144.

The question whether such courses should be compulsory was also answered in a very similar way. As many as $94 \%$ of respondents replied positively: yes, first aid education should be made compulsory. 


\section{WOULD YOU KNOW HOW TO HELP AN INJURED PERSON?}

\section{Would you be able to help an injured person properly?}

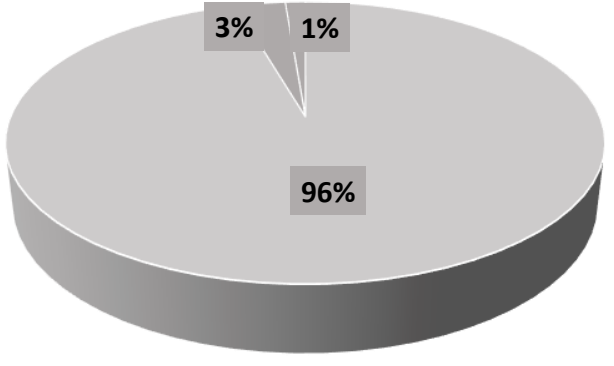

Yes $96 \%=$ No 3\% - I don't know 1\%

Diagram 13. Helping an injured person

Source: Own research, Warsaw 2021, N=144.

As many as $97 \%$ of people rated their skills very highly - in their opinion, they could help an injured person. Clearly, the survey does not verify these answers and there is no way to check their skills. However, when asked "What should a witness to a road accident do?", the respondents answered in the following manner:

- Immediately secure the area of the incident, take care of your own safety, examine the injured party, call emergency services - be specific in your description of the circumstances of the incident, the number of injured individuals and their condition (national services have a preliminary action plan before they reach the scene of the incident);

- First and foremost, inform the relevant services and take care of your own safety and, if this does not pose a threat to your health or life, provide first aid to the injured party to the best of your ability;

- First of all, assess the state of your own safety, and then try to help others and call for assistance from the police/fire brigade/ambulance service.

\section{WHAT DO YOU THINK ABOUT TOPICS CONCERNING SAFETY?}

This question was answered unequivocally by the majority of respondents: it is a very key issue and should be compulsory for all to learn. 


\section{WOULD YOU LIKE TO KNOW MORE ABOUT HOW TO DEAL WITH EMERGENCY SITUATIONS?}

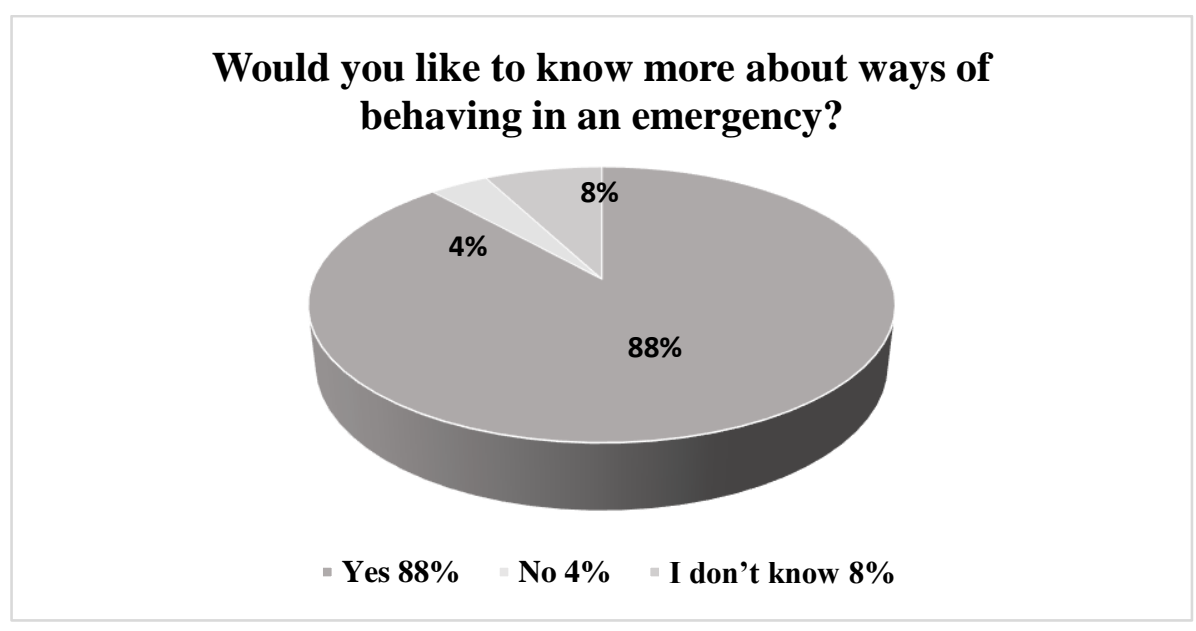

Diagram 14. Ways of dealing with an emergency situation Source: Own research, Warsaw 2021, N= 144.

In the last question, the respondents were asked if they wanted to know more about how to deal with emergency situations. This question was deliberately introduced as the last one in the questionnaire so that the respondents, when expressing their opinions in the previous questions in different areas, could see which issues they have difficulties in. As a result, 93\% of those surveyed considered that they would like to take part in activities where they could learn more about how to deal with different risks. As many as 3\% said they did not want to know more, and $4 \%$ said they just did not know. The latter may be due either to the fact that they consider their knowledge and sufficient skills or to their reluctance to take part in classes on these subjects.

\section{RESULTS SUMMARY}

The aim of the presented research was to check the level of society's knowledge of safety. The research results confirm the hypothesis that the level of society's knowledge of safety is at a high level. It was also important to verify the hypothesis that school-age children and adolescents are better equipped with knowledge and skills to cope in crisis situations than adults, it should be pointed out that the age of about $30 \%$ of respondents was under 25 years old.

The research has shown that the basic source of knowledge concerning threats and danger is mass media, whereas children and adolescents indicated in the first place that the best way to educate themselves about threats is to take classes with safety service representatives. It should also be noted that the media do not only hold an informative function, but also an educational one (not to mention their function as entertainment providers). The social mission of the media involves considering the criteria for choosing the content to be broadcast. ${ }^{15}$

\footnotetext{
${ }^{15}$ P. Czarnecki, Ethics of Media, Warsaw 2008, pp. 18-19., M. Środa, Journalistic ethics: between freedom and responsibility, in: Mass media in social practice, ed. D. Waniek, J. W. Adamowski, Warsaw 2007, pp. 167-175.
} 
Although the media are most often the source of knowledge about threats and risks, it is worth noting that meetings organised with safety specialists at schools contribute significantly to remembering important information about safe behaviour and attitudes. Meetings with representatives of the police, fire brigade, lifeguards, and medical personnel deserve special mention.

It is worth noting that properly implemented safety education should be based on cooperation with specialists from individual safety-related sectors. Of utmost importance was the introduction in 2009 of subject safety education, which then replaced defensive training. When thinking about the quality of education, it is important to update the content related to safety. Education curricula should be adapted to contemporary requirements and the European Union, as well as to the principles of sustainable development. ${ }^{16}$

The results of the preliminary studies have led to the following conclusions on:

\section{Safety perception:}

- Safety is mainly seen as the absence of threats in the surrounding environment (50\%), while detailed answers indicate that the public is aware that this term covers a wide range of issues, and that it is difficult to give a short answer on this subject. The level of this knowledge is high among children and young people (as well as adults).

\section{Personal safety:}

- An important starting point was to determine the respondents' attitude to their own safety. As many as $97 \%$ of them said that it was important to them. This may result in a high level of knowledge concerning many issues related to this subject.

\section{The existence of threats:}

- The awareness of the respondents concerning the occurrence of natural and anthropogenic threats indicates that they are consistent with the place of residence and their occurrence. Among the most frequent threats were traffic accidents (20\%), fires (17\%), storms and hurricanes (14\%), droughts and heat (12\%), and sanitary and epidemiological threats $(8 \%)$. Responses to the remaining threats were at the level of $1-4 \%$. The ability to deal properly with these risks was assessed by respondents at a high level (very good,, good and rather good: over 90\%). There was a high response rate for participating in safety classes (74\%).

\section{Sources of information:}

- Nowadays, most people obtain information about safety mainly from the Internet or television ( $85 \%$ in total). It is therefore important to know how to select the right reliable sources. However, when asked how safety should be taught most effectively, more than half indicated that it should come directly from safety specialists: representatives of

\footnotetext{
${ }^{16}$ Z. Jezierski, Establishment and development of education for safety as a didactic and educational system in Polish schools, "Interdisciplinary Social Studies", 2017 1(3), p. 7., P. Kłos, Education for security as an element of defense preparation of young people in: Contemporary defense challenges, ed. J. Walczak, C. Sochala, Wyszków 2013, pp. 146150., A. Pieczywok, Selected problems in the field of education for safety, Warsaw 2011, pp. 98-99.
} 
uniformed and emergency services. As many as $76 \%$ are interested in the subject of safety, and they obtain information themselves. This is a very satisfactory result, and it is consistent with the previous answers and the attitudes of respondents.

\section{Interest in safety:}

- The topics that have been identified as the most interesting for the respondents show that they are both professional interests, but also those with which they meet on an everyday basis. More than half of the respondents were able to name social campaigns and programmes on safety issues. In addition, $80 \%$ of the respondents described social campaigns and demonstrations as the most effective way to raise public awareness of safety. It is worth mentioning that the respondents were able to easily name both online portals and safety apps. Social campaigns can take on different forms depending on the objectives, standards, and rules, as well as the impact time. They can be persuasive or informative.

Responsibility for safety: ${ }^{17}$

- Responsibility for safety activities are assigned to governmental, local government, and emergency services. It was also important to underline that each one of us has an impact on our own personal safety.

Assessment of practical skills:

- This included questions concerning participation in evacuation drills, training on anti-terrorist issues, skills in providing premedical first aid, and ability to help injured persons. Most of the people have taken part in evacuation drills. Unfortunately, this was not a satisfactory result (compared to the statutory obligation). Although it concerns facilities, every person should take part in this type of simulation at least once in their life. Regarding the participation in first aid courses, more than $90 \%$ of the respondents took part in such courses. More than $90 \%$ believed these courses were needed and should be compulsory. As many as $97 \%$ of the respondents believed that they would be able to help an injured person (it should be added, however, that the survey was not designed to verify these skills). An interesting result is the indicator concerning participation in anti-terrorism training. It is not an obligatory subject - it involves only voluntary participation; however, most of the respondents showed great interest in this subject. It should be mentioned that this question was included in the survey due to the fact that in recent times terrorism has become one of the greatest threats to the modern world. ${ }^{18}$

A summary:

The survey summary was very positive; the majority of respondents considered the subject of safety to be essential and necessary and that it should be mandatory for all. Nearly

\footnotetext{
${ }^{17}$ Cf. A. Lusińska, Social campaigns in public service, Warsaw 2019, pp. 61-64; B. Dobek- Ostrowska, Political and public communication, Warsaw 2012, pp. 237-241.

${ }^{18}$ B. Hołyst, Social Security, Warsaw 2015, p. 451.
} 
$99 \%$ of the respondents replied that they would like to continue to participate in the process of acquiring knowledge about safety.

\section{DISCUSSION}

The analysis of the literature, available research and the presented research results indicate the need to take action in the education of the society in the field of security, which is one of the most effective forms of counteracting threats.

Security is a broad and multidimensional concept. It is difficult to define it unequivocally. Therefore, the main educational emphasis should cover not only those responsible for it, the analysis of local threats should be taken into account. This will allow for differences in the perception of threats to be taken into account.

As the research results show, the importance of education for security should not be limited to formal education. Education for safety should be a comprehensive, properly programmed activity, consisting in the cooperation of many government and local government institutions, NGOs, services, and educational institutions. Thanks to this, we can cover all target groups of all ages and backgrounds. Cooperation with other countries in this area is also important.

\section{CONCLUSIONS}

Summarising the subject matter undertaken, it is worth emphasising that our current times are abound in various types of dangerous and threatening events. In addition, information reaches the recipient in an instant by means of mass media. Present-day individuals try to be more conscious and, consequently, better prepared to take actions to prepare for crisis situations. ${ }^{19}$

The importance of safety issues in the systemic perspective is becoming important. Preparation of appropriate structures of central as well as local government and selfgovernment, non-governmental institutions, the education system and self-education, and then providing them with appropriate coordination and cooperation patterns may constitute the basis for building a high-level safety system. This system would be constantly improved and actively supported - and developed - by individual persons themselves. ${ }^{20}$

The implementation of assumptions related to raising public awareness in the area of safety must be carried out on many levels using all forms of education mentioned at the beginning of this article. As the results of the research show, school teachers and educators (representatives of the uniformed services who conduct classes at schools) play a substantial role in shaping society's awareness and thus creating a system of citizen safety.

\footnotetext{
${ }^{19}$ M. Beskosty, The Functions and the role of media in crisis management, "Security studies", 2018 Iss. 3, pp. 190-197.

${ }^{20} \mathrm{Cf}$ A. Pieczywok, Education for safety in the face of threats and challenges of modern times, Warsaw 2012, pp. 106116.; M. Łukawska, Education as one of the guarantors of security in Poland, "De Securitate et Defensione. O Bezpieczeństwie i Obronności” 2016 2(2), pp. 150-152.
} 
The opportunities for the society to obtain knowledge and openness, which will significantly contribute to raising the level of safety of all people, should be recognised. A valuable insight from the study is that education should concern not only the transfer of knowledge and skills but also effective and professional information acquisition. This is important in the era of great access to information, as it is important to obtain it from reliable and credible sources. The principles of sustainable development should be disseminated on a mass scale and should form the basis for all activities, especially those related to educating the population. ${ }^{21}$

An important issue raised by the study was the use of modern information and communication technologies in educating for sustainable development. Attractive tools, thanks to their multifunctional nature, can help satisfy one's own cognitive needs. In time, they allow young people to become creators of the information transmitted online. There is a chance of using this model of self-education in shaping society's awareness in this area and to become acquainted with the problem of dealing with selected threats, which will promote the principles of sustainable development. ${ }^{22}$

To sum up, it is worth considering the question: what are the challenges facing the modern safety education system in accordance with the principles of sustainable development? First of all, it is important to constantly motivate society to obtain knowledge and skills on how to behave in times of crisis and how to protect themselves against threats. It should be remembered that each of us plays a role in our own personal safety. The second issue is the ability to choose reliable sources and rely on facts. Building a system of education for safety requires cooperation between governmental bodies, local governments, non-governmental organisations and, above all, the media.

The criteria that largely determine our safety today are knowledge, skills, reason, the ability to logically combine facts, and draw conclusions, as well as imagination, which allows us to predict certain events. The willingness to follow and have trust in government directives issued during the crisis is also vital.

\section{BIBLIOGRAPHY}

Agenda 2030 - Education and Lifelong Learning in the Sustainable Development Goals. Agenda 2030 - Education and Lifelong Learning in the Sustainable Development Goals. IPE International Perspectives in Adult Education. 2016.

Batorczak Anna. 2013. Education for Sustainable Development in Poland and Great Britain doctoral dissertation. Warsaw: University of Warsaw.

Beskosty Małgorzata.2018. "Funkcje i rola mediów w zarządzaniu kryzysowym”. [The Functions and the role of media in crisis management]. Security studies. issue 3. pp. 190-197.

Buchcic Elżbieta. 2008. „Edukacja dla zrównoważonego rozwoju w szkołach ponadgimnazjalnych". [Educating young people for sustainable development at different stages of teaching] Studia Ecologiae et Bioethicae 6. pp.347-358.

\footnotetext{
${ }^{21}$ K. Sikora, Education for safety in a Polish school, "International Security Yearbook,” 2019, pp. 112-117.

${ }^{22}$ D. Morańska, Contemporary e-learning - socio-pedagogical problems in: Human, media, education, ed. J. Morbitzer,

D. Morańska, E. Musiał, Katowice 2016, pp. 112.
} 
Cebrian Gisela. Junyent Merce. Mula Ingrid. "Competencies in Education for Sustainable Development: Emerging Teaching and Research Developments." [Kompetencje w edukacji na rzecz zrównoważonego rozwoju: nowe nauczanie i rozwój badań]. Sustainability 2020. 12(2). 579; https://doi.org/10.3390/su12020579.

Czarnecki Paweł. 2008. Etyka mediów. [Ethics of Media]. Warsaw: Difin. pp. 1-14.

Czupryński Andrzej. 2015. Bezpieczeństwo w ujęciu teoretycznym. [Theoretical security]. Bezpieczeńśtwo: teoria- badania - Praktyka. [Safety: Theory - Research - Practice]. ed. Andrzej. Czupryński. Bernard. Wiśniewski. Jacek. Zboina. pp. 9-25.Józefów: CNBOP-PIB.

Dobek- Ostrowska Bogusława. 2012. Komunikowanie polityczne i publiczne. [Political and public communication]. Warsaw: PWN.

Drabik Krzysztof. 2013. Bezpieczeństwo personalne i strukturalne. [Personal and structural security]. Warsaw: National Defense University.

McKeown Rosalyn. "Education for Sustainable Development". [Edukacja dla zrównoważonego rozwoju] Toolkit. . Version 2. July 2002. Center for Geography and Environmental Education. University of Tennessee. pp.13-23.

Grabowska-Lepczak Izabella. 2017. Edukacja dla bezpieczeństwa. Aspekty praktyczne I teoretyczne. [Education for safety. theoretical and practical aspects]. Warsaw: Publisher The Main School of Fire Service.

Gruchelski Marek. Niemczyk Józef.. 2016. „Agenda narodów zjednoczonych na rzecz zrównoważonego rozwoju 2030 i cele zrównoważonego rozwoju - szanse realizacji celów". [The 2030 Agenda for sustainable development goals and sustainable. development goals - chances of implementation]. in: Postępy techniki przetwórstwa spożywczego 1/2016. pp. 22-125.

Hołyst Bruno.2015. Bezpieczeństwo społeczeństwa. Social Security.Warsaw: PWN.

Jezierski Zdzisław. 2017. "Powstanie i rozwój edukacji dla bezpieczeństwa jako systemu dydaktyczno-wychowawczego w polskich szkołach". [Establishment and development of education for safety as a didactic and educational system in Polish schools]. In Interdisciplinary Social Studies. Issue 1 (3). pp. 7-22.

Kioupi Vasilij. Voulvoulis Nikolaos. 2019. "Education for Sustainable Development: A Systemic Framework for Connecting the SDGs to Educational Outcomes. Sustainability 2019”. [Edukacja na rzecz zrównoważonego rozwoju: systemowe ramy łączenia celów zrównoważonego rozwoju z wynikami nauczania. zrównoważony rozwój. 11. 6104; doi:10.3390/su11216104. pp.1-18.

Kłos Piotr. 2013. Education for security as an element of defense preparation of young people. and: Contemporary defense challenges. ed. J. Walczak. C. Sochala. Wyszków Kopaliński Władysław. 1999. Słownik wyrazów obcych. [Dictionary of foreign words and phrases]. Warsaw: Muza S.A.

Kral Ewa. 2006. Edukacja ekologiczna społeczności lokalnych i świadomość ekologiczna mieszkańców miejskiej zabudowy mieszkaniowej [Environmental education of local communities and ecological awareness of urban housing residents]. in: Edukacja ekologiczna społeczności lokalnych. [Environmental education of local communities]. ed. Ligia. Tuszyńska. Warsaw: WUW. 
Kuzior Anna. 2014. „Dekada Edukacji dla Zrównoważonego Rozwoju”. [Education for Sustainable Development]. Zeszyty Naukowe Politechniki Śląskiej. 2014. Series: Organizacja i Zarządzanie from72 Coll. Issue 1918. pp. 92-93.

Leicht Alexander. Combes Bernard. Byun Won Jung. Agbedahin Adesuwa Vanessa. 2018.

"From Agenda 21 to Target 4.7. the development of Education for Sustainable Development”. [Od Agendy 21 do celu 4.7. rozwój Edukacji dla Zrównoważonego Rozwoju]. Alexander Leicht. Heiss Julia. Byun Won Jung. Issues and trends in Education for Susitainable Development. UNESCO Publishing. pp. 1-271.

Lorek Marlena. 2017. „Edukacja dla bezpieczeństwa jako ogniwo w systemie bezpieczeństwa”.

[Education for Security as a Link in the Security System]. in: "Edukacja - Technika Informatyka" No. 4/22/2017. www.eti.rzeszow.pl. DOI: 10.15584/eti.2017.4.37. pp. 286-287. Lusińska Anna. 2019. Kampanie społeczne w służbie publicznej. [Social campaigns in public service]. Warsaw: CEDEWU.

Łukawska Marta. 2016. "Edukacja jako jeden z gwarantów bezpieczeństwa w Polsce". [Education as one of the guarantors of security in Poland]. in: Issue 2(2)/2016 desecuritate.uph.edu.pl. pp. 150-152.

Marciniuk Mirosława. 2015. Edukacja dla bezpieczeństwa - warunek ochrony interesów narodowych. w: Edukacja dla bezpieczeństwa. Strategia bezpieczeństwa narodowego. [Education for security - a condition for safeguarding national interests]. in: education for security. National security strategy - social and economic executive support. ed. Marek. Ilnicki. Jakub. Kufel. pp.23-35. Poznań: College of Security Publishing.

Morańska Danuta. 2016. Współczesny e-learning - problemy społeczno-pedagogiczne. [Contemporary e-learning - socio-pedagogical problems]. in: Human. media. education. [Człowiek. media. edukacja] ed. Janusz Morbitzer. Danuta Morańska. Emilia Musiał. pp.115-121. Katowice: Published by: Studio NOA for University of Silesia.

Olak Karolina. Olak Antoni. "Współczesne rozumienie bezpieczeństwa narodowego". [Modern understanding of national security]. SCIENTIFIC ARTICLES. Acta Scientifica Academiae Ostroviensis. ASO.A.7(1)/2016/467-480. pp.467-480.

Rozporządzenie Ministra Spraw Wewnętrznych i Administracji w sprawie ochrony przeciwpożarowej budynków. innych obiektów budowlanych i terenów. Dz. $\mathrm{Nr} 109$. poz.719. Ordinance of the Minister of the Interior and Administration on the fire protection of buildings. other building structures and areas. Journal of Laws 2010 no. 109 item 719.

Pieczywok Andrzej. 2012. Edukacja i bezpieczeństwo wobec zagrożeń społecznych i cywilizacyjnych. [Education for safety in the face of threats and challenges of modern times]. Warsaw: AON.

Pieczywok Andrzej. 2011. Wybrane problemy z zakresu edukacji dla bezpieczeństwa konteksty zagrożenia wyzwania. [Selected problems in the field of education for safety]. Warsaw: AON. Riegert Dorota. Wachnik Monika. 2016. "Importance of education for safety". \{Znaczenie edukacji dla bezpieczeństwa]. Journal of Modern Science. volume 3/30/2016. pp. 317-333.

Ropski Janusz. 2013. Dydaktyka szczegółowa edukacji dla bezpieczeństwa. [Detailed didactics of education for safety]. Katowice: AWF.

Sandner Jan. 2008. "Wybrane aspekty procesów środowiskowych holistycznej edukacji przyrodniczej w świetle idei zrównoważonego rozwoju”. [Selected aspects of 
environmental processes of holistic nature education in the light of the idea of sustainable development]. in: Sustainable development problems. Vol. 3. Issue 2. pp. 69-80.

Shih-Yeh Chen. Shiang-Yao Liu. 2020. "Developing Students' Action Competence for a Sustainable Future: A Review of Educational Research". Sustainability 2020. 12(4). 1374; doi.org/10.3390/su12041374. pp.1-14.

Skrabacz Anna. 2015. Charakter narodowy Polaków i jego wpływ na proces edukacji dla bezpieczeństwa Polaków. [The national character of Poles and its impact on the education process for the safety of Poles]. in: Security as an educational process. ed. Andrzej. Pieczywok. Krzysztof. Loranty. pp. 77-83.Warsaw: AON.

Sikora-Wojtarowicz Karina. 2019. "Edukacja dla bezpieczeństwa w Polskich szkołąch. Education for safety in a Polish school." International Security Yearbook. https://doi.org/10.34862/rbm.2017.1.7. pp. 112-117.

Special edition: progress towards the Sustainable Development Goals Report of the SecretaryGeneral. Economic and Social Council. Economic and Social Council. E/2018/64, pp. 1-19.

Stankiewicz Alicja. 2005. Wdrożenie założeń zrównoważonego rozwoju w deklaracji studentów fizyki. [Implementation of sustainable development assumptions in the declaration of students of physics]. in: Education and sustainable development in a unifying Europe. ed. E. Rydz and A. Kowalik.Słupsk: Publisher of the Pomeranian Pedagogical Academy.

Środa Magdalena. 2007. Etyka dziennikarska: między wolnością a odpowiedzialnością. [Journalistic ethics: between freedom and responsibility]. in: Mass media in social practice. ed. D. Waniek. J. W. Adamowski. pp. 167-175. Warsaw: Aspraw - JR.

United Nations Conference on Environment \& Development. Rio de Janerio. Brazil. 3 to 14 June 1992. AGENDA 21. Chapter 36.

Włodarczyk Ewelina. 2019. Kwalifikacje nauczycieli edukacji dla bezpieczeństwa. [Qualifications of education teachers for safety. Security of the modern state]. National dimension. ed. J. Falecki. P. Łubiński. pp. 218-220. Kraków: Publisher Styl Anna Dura. Żeber-Dzikowska Ilona.2005. Edukacja ekologiczna w XXI wieku - edukacja dla wszystkich. [Ecological education in the 21st century - education for all]. in: Education and sustainable development in a unifying Europe. p. 64. Słupsk: Pomeranian Pedagogical Academy. 